\title{
THE COMPLEMENT-FIXATION TEST IN THE DIAGNOSIS OF HERPES SIMPLEX INFECTIONS
}

\author{
BY \\ N. L. MODI AND J. O'H. TOBIN \\ From the Department of Bacteriology, University of Manchester
}

(RECEIVED FOR PUBLICATION FEBRUARY 14, 1955)

As infection with herpes simplex virus appears to be more common than was formerly supposed, laboratory confirmation of the role of this virus in lesions of the mouth, central nervous system, skin, and liver is being sought more often.

The simplest laboratory method for diagnosis is by the complement-fixation test, and a number of different methods of making antigen have been recommended since 1929, when Bedson and Bland described their method for this procedure. The correlation between the complement-fixing and neutralization tests has been shown to be very close if not always absolute (Hayward, 1949; Dudgeon, 1950 ; Holzel, Feldman, Tobin, and Harper, 1953).

A comparison of some of these methods was made during the performance of routine tests for herpes simplex infection and it was thought that a report of this experience might be of interest.

\section{Methods of Preparing Antigens}

Two strains of virus were used, "E.W.H." isolated from a patient with encephalitis, and " $\mathrm{McC}$," which was egg adapted. Both were used for producing antigens from the chorio-allantoic membrane, the E.W.H. strain for guinea-pig, mouse, and rabbit inoculation, and the McC strain for yolk sac inoculation. Control antigens were made in each case from the corresponding normal tissue.

A. Chorio-allantoic Membrane (C.A.M.) Antigens. -Following inoculation with a dose of virus which produced confluent lesions after $\mathbf{4 8}$ hours, the chorioallantoic membranes were harvested and antigen prepared by the methods of the following :

(1) Hayward (1949).-The membranes were ground in a pestle and mortar with $0.5 \mathrm{ml}$. of $20 \%$ Hartley broth in normal saline, kept at room temperature for two hours, and centrifuged at 2,500 r.p.m. for 15 minutes; the supernatant was removed and used as antigen.

(2) Dudgeon (1950).-Infected membranes were ground with $2 \mathrm{ml}$. of diluent per membrane, frozen and thawed six times, and centrifuged in an angle machine at 5,000 r.p.m. for 30 minutes. The supernatant was used as antigen.

(3) Modification (1) of Hayward's Method.-Before centrifugation the C.A.M. extract was frozen at $-30^{\circ} \mathrm{C}$. for 10 days.

(4) Modification (2) of Hayward's Method.Chloroform, $0.05 \mathrm{ml}$, as recommended by Hoyle (1948) for preparing influenza complement-fixing antigen was added to each millilitre of antigen, the mixture shaken, and left at $4^{\circ} \mathrm{C}$. overnight. After light centrifugation the supernatant fluid was used as antigen.

(5) Casals (1949).--Infected membranes were treated by the method which is described later (section C2).

B. Guinea-pig Pad Antigens.-Two methods were used.

(1) Bedson and Bland (1929).-Four to five days after intradermal inoculation of the footpads of both young and adult guinea-pigs, the animals were killed and the pads removed. They were cut into small pieces and ground, using glass beads and $4-5 \mathrm{ml}$. normal saline per pad as diluent. After being kept at room temperature for three to four hours, the supernatant was pipetted off and used as antigen.

(2) Modification of Bedson and Bland's Method.Antigen thus prepared was treated with chloroform as already described (section A4).

C. Mouse Brain Antigens.-Casals' two methods were used.

(1) Casals and Palacios (1941).-Brains of herpesinfected mice were emulsified in 10 volumes of normal saline containing $2 \%$ inactivated guinea-pig serum. The emulsion was held at $4^{\circ} \mathrm{C}$. overnight and centrifuged at 2,500 r.p.m. for 30 minutes. After freezing and thawing the supernatant five times it was spun at 4,500 r.p.m. for 30 minutes in the angle centrifuge. The supernatant of this spinning was used as antigen.

(2) Casals (1949).-Brains of infected mice were removed and weighed, 20 volumes of acetone added, and the mixture emulsified in an "atomix" blender for two minutes in the cold. After spinning in a horizontal centrifuge at 1,500 r.p.m. for one minute, the supernatant was replaced with 20 volumes of 
acetone, then 20 volumes of acetone-ether mixture followed by two 20-volume changes of ether alone. Between each change the mixture was allowed to stand for 20 minutes at room temperature with occasional shaking and then centrifuged. After the last ether extraction the material was dried in vacuo and the residue redissolved in 3 volumes of normal saline and kept at $4^{\circ} \mathrm{C}$. overnight. After centrifugation at 10,000 r.p.m. for one hour the supernatant was removed and used as the antigen.

D. Allantoic and Amniotic Fluid Antigens.-Two processes were needed.

(1) Gajdusek, Robbins, and Robbins (1952).-After inoculation of the yolk sac of 8-9-day-old developing chick embryos with a dose of virus which allowed most of the eggs to survive for four to six days, the allantoic and amniotic fluids were harvested and used directly as antigen either separately or after pooling. If a large amount of urates were present the fluids were dialysed in $\mathrm{M} / 100$ phosphate buffer overnight.

(2) Hayward (1949).--Infective C.A.M. extracts were inoculated directly into the allantoic cavity and the fluid harvested after three to five days. Amniotic fluid antigens were not obtained by this form of inoculation.

\section{Technique of the Complement-Fixation Tests}

For routine antibody titrations the optimal antigen dilution was obtained by a chessboard titration using twofold dilutions of antigen and immune serum. For determining the effect of chloroform and other agents on the antigen, dilutions of antigen were titrated against a constant volume of a specified dilution of serum, which was four times that volume which gave $100 \%$ complement fixation with the optimal dilution of antigen.

The five-volume test was used with $0.2 \mathrm{ml}$. of each component. Complement was guinea-pig serum diluted to give two M.H.D.s per unit volume. Fixation proceeded overnight at $4^{\circ} \mathrm{C}$. The haemolytic system was $2 \%$ sheep cells +5 M.H.D. haemolysin. Results were read after 30 minutes in the water-bath at $37^{\circ} \mathrm{C}$. End-points were taken as $75-100 \%$ fixation in most instances.

\section{Results}

The allantoic and amniotic fluids and the extracts of C.A.M. and guinea-pig pads, in which neither chloroform nor acetone and ether were used in their preparation, yielded antigens of adequate concentration for routine complement-fixation tests with herpes simplex virus. With both C.A.M. and pad antigens, chloroform reduced the yield of antigen at least fourfold and the acetone and ether even more than this when compared with untreated controls. The yield from infected mouse brains was very poor, the extracts having to be used undiluted in order to obtain adequate fixation, and some of these preparations tended to be anti-complementary at this concentration. These findings are similar to those of Garabedian (1953) with his ether-extracted antigens.

However, with similar preparations prepared as controls from normal, non-infected materials, 23 of 102 sera $(22.6 \%)$ reacted non-specifically with C.A.M. and seven of $49(14.3 \%)$ with guinea-pig pad while none of 109 sera reacted in this way with allantoic or amniotic fluid (Table I). Fifteen of

TABLE I

PERCENTAGE OF NON-SPECIFIC FIXATION WITH CONTROL ANTIGENS FROM UNINFECTED MATERIAL

\begin{tabular}{c|c|c|c}
\hline $\begin{array}{c}\text { Method of } \\
\text { Preparing Antigen }\end{array}$ & $\begin{array}{c}\text { No. of } \\
\text { Sera } \\
\text { Tested }\end{array}$ & $\begin{array}{c}\text { No. Reacting } \\
\text { Non- } \\
\text { specifically }\end{array}$ & $\begin{array}{c}\text { Percentage } \\
\text { Non-specific } \\
\text { Reactions }\end{array}$ \\
\hline $\begin{array}{l}\text { C.A.M. (Hay:vard, 1949) } \\
\begin{array}{c}\text { Guinea-pig pad (Bedson } \\
\text { and Bland, 1929) }\end{array}\end{array}$ & 102 & 23 & $22 \cdot 6$ \\
$\begin{array}{c}\text { Allantoic-amniotic fluid } \\
\text { (Gajdusek, Robbins and } \\
\text { Robbins, 1952) }\end{array}$ & 109 & 0 & $14 \cdot 3$ \\
\hline
\end{tabular}

these sera were tested in a dilution of 1 in 4 for non-specific fixation with preparations from both the chorio-allantoic membrane and the guinea-pig pad. Of these, 12 reacted with both, two with C.A.M. but not with guinea-pig pad and one in the reverse way. This would suggest that the nonspecific factors were not identical in the guinea-pig and C.A.M. The 12 sera reacting with both were then used to determine the number of non-specific reactions obtained with preparations of normal

TABLE II

COMPARISON OF METHODS OF PREPARING ANTIGENS: I, NON-SPECIFIC FIXATION WITH PREPARATIONS OF NORMAL TISSUE AND SELECTED SERA*; II, POTENCY OF SPECIFIC ANTIGEN PREPARED FROM INFECTED TISSUE

\begin{tabular}{|c|c|c|c|}
\hline \multirow[b]{2}{*}{$\begin{array}{l}\text { Method of } \\
\text { Preparation }\end{array}$} & \multicolumn{2}{|r|}{ I } & \multirow{2}{*}{$\begin{array}{c}\text { II } \\
\text { Potency of Herpes } \\
\text { Simplex C.F. } \\
\text { Antigen Prepared } \\
\text { from Infected } \\
\text { Tissues }\end{array}$} \\
\hline & $\begin{array}{l}\text { No. of } \\
\text { Sera } \\
\text { Tested }\end{array}$ & $\left|\begin{array}{c}\text { No. of Sera } \\
\text { Reacting } \\
\text { Non-speci- } \\
\text { fically }\end{array}\right|$ & \\
\hline $\begin{array}{l}\text { C.A.M.: } \\
\text { Dudgeon (1950) } \\
\text { Hayward }(1949)+ \\
\text { chloroform }\end{array}$ & $\begin{array}{r}12 \\
6\end{array}$ & $\begin{array}{r}10 \\
2\end{array}$ & $\begin{array}{l}\text { Good } \\
\text { Fourfold loss in } \\
\text { antigenicity } \\
\text { after CHCl } \\
\text { treatment }\end{array}$ \\
\hline $\begin{array}{l}\text { Hayward } \\
\text { freezing } \\
\text { Casals (1949) }\end{array}$ & $\begin{array}{l}6 \\
5\end{array}$ & $\begin{array}{l}6 \\
0\end{array}$ & $\begin{array}{l}\text { Good } \\
\text { Poor }\end{array}$ \\
\hline $\begin{array}{l}\text { Guinea-pig pad: } \\
\text { Antigen }+\mathrm{CHCl}_{3} \ldots\end{array}$ & - & - & $\begin{array}{l}\text { Fourfold loss in } \\
\text { antigenicity } \\
\text { after } \mathrm{CHCl}_{3} \\
\text { treatment }\end{array}$ \\
\hline $\begin{array}{l}\text { Mouse brain antigen: } \\
\text { Casals (1949) } \\
\text { Casals and Palacios } \\
(1941)\end{array}$ & 2 & 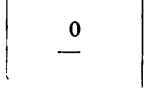 & $\begin{array}{l}\text { Poor } \\
\text { Nil }\end{array}$ \\
\hline
\end{tabular}
* Sera reacting non-specifically with Hayward's C.A.M. antigen
(1949). 
tissues made by other methods and their modifications as used for making specific antigens. The results are given in Table II. As can be seen, the only two methods which reduced the non-specific reactions were treatment with chloroform and Casals' method, both of which, however, gave a poor yield of specific antigen.

Dudgeon (1950) has recommended inactivating human sera at $62^{\circ} \mathrm{C}$. for 15 minutes to nullify the non-specific complement-fixing factors in them. We have found that such treatment, although reducing the non-specific effect, also reduced in some sera specific antibody. With four anti-herpetic sera, two showed a drop in titre. Three other sera containing antibodies to lymphocytic choriomeningitis virus also showed a lower titre when heated similarly. If the sera were diluted in saline before heating, this fall in antibody did not occur (Felix and Olitzki, 1929), but neither was the non-specific factor reduced, for it also was protected by the diluent. The effect of heating on these four sera which contained relatively labile antibodies to these two viruses is given in Table III.

TABLE III

EFFECT OF HEAT ON ANTIBODIES TO HERPES SIMPLEX AND LYMPHOCYTIC CHORIO-MENINGITIS VIRUSES

\begin{tabular}{|c|c|c|c|c|c|c|}
\hline \multirow[b]{2}{*}{ Serum } & \multirow[b]{2}{*}{$\begin{array}{l}\text { Test } \\
\text { Virus }\end{array}$} & \multirow[b]{2}{*}{$\begin{array}{l}\text { Serum } \\
\text { Heated }\end{array}$} & \multicolumn{4}{|c|}{ C.F. Titre after } \\
\hline & & & $\begin{array}{l}56^{\circ} \mathrm{C} . \\
\text { for } \\
30 \mathrm{~min} .\end{array}$ & $\begin{array}{l}56^{\circ} \mathrm{C} . \\
\text { for } \\
60 \mathrm{~min} .\end{array}$ & $\begin{array}{l}56^{\circ} \mathrm{C} \text {. for } 30 \\
\mathrm{~m}^{\prime} \mathrm{n} .+62^{\circ} \mathrm{C} \text {. } \\
\text { for } 15 \mathrm{~min} .\end{array}$ & $\begin{array}{l}62^{\circ} \mathrm{C} . \\
\text { for } \\
15 \mathrm{~min} .\end{array}$ \\
\hline $\begin{array}{l}\text { D } \\
\text { L } \\
\text { C }\end{array}$ & $\begin{array}{l}\text { Herpes } \\
\text { Lympho- } \\
\text { cy:ic } \\
\text { chorio- } \\
\text { meningitis }\end{array}$ & $\begin{array}{c}\text { Neat } \\
, " \\
, "\end{array}$ & 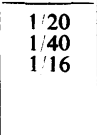 & $\begin{array}{ll}1 & 20 \\
140 \\
1 / 16\end{array}$ & $\begin{array}{l}15 \\
1 / 20 \\
-\end{array}$ & $\begin{array}{l}1 / 5 \\
1 / 20 \\
1 / 8\end{array}$ \\
\hline $\begin{array}{l}\mathbf{C} \\
\mathbf{R}\end{array}$ & ," & $\underset{\text { Neat }}{\text { Diluted }}$ & $\begin{array}{l}1 / 16 \\
18\end{array}$ & $\begin{array}{l}116 \\
18\end{array}$ & $\begin{array}{l}1 / 2 \\
1 / 2\end{array}$ & $\begin{array}{l}1 / 16 \\
1 / 4\end{array}$ \\
\hline
\end{tabular}

Non-specific reactions were much more frequent during the spring and early summer than at other times of the year, an observation also noted with lymphocytic chorio-meningitis antigen prepared from guinea-pig spleen.

The preparation of antigen control also caused some difficulty. Six controls prepared in the same way from normal chorio-allantoic membranes were titrated against a serum containing nonspecific factors at high dilution. The antigens were tested at dilutions of 1 in 10 and 1 in 20 ; two of them gave no reaction with serum diluted 1 in 5 ; a third reacted with serum at 1 in 10 and 1 in 5 respectively for the two antigen dilutions; a fourth with serum at 1 in 20 and 1 in 5 ; a fifth with serum at 1 in 5 for the stronger dilution of antigen control ; and the sixth with serum at more than
1 in 160 with both dilutions of control antigen. In order to use the normal C.A.M. extract as a con- 을 trol, it was necessary to perform a chessboard $\overrightarrow{\vec{F}}$ titration with it against a serum reacting non- $\stackrel{0}{\rightarrow}$ specifically just as was done with the viral antigens. The allantoic and amniotic fluids did not react in this way. Although often these infected fluids could not be used as specific antigens at as high a $\stackrel{\mathbb{Q}}{\Omega}$ dilution as antigens prepared from the C.A.M. or क guinea-pig pad and required more eggs for the $\vec{\circ}$ same number of tests, they were the antigens of choice.

Of a hundred human sera tested, 80 contained neutralizing antibody and all of these except three ?? had complement-fixing antibody to the allantoic or $\infty$ amniotic antigens. These three sera presumably $\vec{i}$ had enough antibody for detection by the more $\stackrel{0}{N}$ sensitive neutralization test but not enough to fix 웅 the amount of complement used in the complement-fixation test. Hayward (1949) and Holzel $z$ et al. (1953) found an occasional serum which contained neutralizing antibodies but which did not fix complement with either allanto:c or chorioallantoic membrane antigens. No sera fixed complement specifically with these antigens which did $\vec{\oplus}$ not contain neutralizing antibodies.

With allantoic-amniotic antigens titres of com plement-fixing antibody in human sera varied from 1 in 2 to 1 in 32 in different sera. The work of Brown (1953) would indicate that the antibodies involved in the complement-fixation test with the $\stackrel{\mathbb{Q}}{\Omega}$ chorio-allantoic membrane antigen were different $\overrightarrow{\overrightarrow{\vec{A}}}$ from those reacting in the neutralization test. In $\frac{0}{3}$ the case of allantoic-amniotic antigens, the com- $\bar{P}$ parison between the titre of the neutral zing and complement-fixing antibodies in seven human sera would suggest that they were the same, the ratio ? of the one to the other being constant within the error of the neutralization test (see Table IV). This point has yet to be clarified, but if it is correct

TABLE IV

RELATIONSHIP OF TITRES OF NEUTRALIZING AND $D$ COMPLEMENT-FIXING ANTIBODIES IN HUMAN SERA O

\begin{tabular}{|c|c|c|c|}
\hline \multirow[b]{2}{*}{ Serum } & \multicolumn{2}{|c|}{ Reciprocals of } & \multirow{2}{*}{$\begin{array}{r}\text { Ratio } \\
\text { (a) } /(\text { b) }\end{array}$} \\
\hline & $\begin{array}{c}\text { (d) } \\
\text { PD } \\
\text { (do }\end{array}$ & $\begin{array}{l}\text { (b) } \\
\text { Complement- } \\
\text { fixing Titre }\end{array}$ & \\
\hline $\begin{array}{l}1 \\
2 \\
3 \\
4 \\
5 \\
6 \\
7\end{array}$ & $\begin{array}{r}118 \\
33 \\
142 \\
124 \\
37 \\
36 \\
37\end{array}$ & $\begin{array}{l}60 \\
40 \\
80 \\
80 \\
40 \\
30 \\
40\end{array}$ & $\begin{array}{l}1.97 \\
08 \\
18 \\
17 \\
0.9 \\
1.2 \\
0.9\end{array}$ \\
\hline
\end{tabular}

* $P D_{50}=$ Dilution of serum neutralizing $50 \%$ of the expected number of pocks produced by the test virus. 
it would place the complement-fixing antigens of herpes simplex virus in a similar category to those of mumps (Henle, Harris, and Henle, 1948).

Using allantoic-amniotic antigens, we were unable to demonstrate complement-fixing antibodies in guinea-pigs which, after repeated injection with herpes virus, had produced neutralizing antibody. After the corneal scarification of rabbits, both complement-fixing and neutralizing antibodies appeared simultaneously, reaching a maximum in five to six weeks and remaining at that level for at least three months.

Although the allantoic-amniotic antigens are to be preferred for the diagnosis of herpes simplex infection by complement fixation, certain points in their preparation and use must be noted.

(1) An egg-adapted strain is necessary to produce a high enough titre of virus to give complement fixation. In our hands the $\mathrm{McC}$ strain was satisfactory while the E.W.H., which had only been through 10 egg passages, was not, a titre of $2 \times 10^{7}$ pocks per $\mathrm{ml}$. being necessary for minimal fixation.

(2) The dose used must be such as to ensure survival of embryos for at least four days after yolk sac inoculation, as those dying earlier than this rarely yielded enough virus for satisfactory antigen production. Eggs should be candled twice daily and harvested just before or immediately after death of the embryo. Fluid contaminated by yolk should be discarded.

(3) To find the optimal dilution for use in diagnostic tests, the chessboard titration must be performed. The easier method of testing falling dilutions of antigen against a constant serum dilution is not satisfactory, as serum with a low titre of complement-fixing antibody may be missed if the latter method is used.

(4) If the standard serum used as the control shows a titre less than the usual value, the test should be repeated.
(5) As $3 \%$ of sera with neutralizing antibody were negative by complement fixation, it might be advisable to ensure that samples were not procomplementary, and to perform a neutralization test in certain of these cases.

(6) Excess complement in the tests should be avoided, as 2 M.H.D.s appeared to be the largest amount that could be used satisfactorily in our complement-fixing system.

\section{Summary}

Different methods recommended for the preparation of comp'ement-fixing antigen with herpes simplex virus were compared. The most satisfactory antigen was infected allantoic or amniotic fluid of developing chick embryos, although the yield was not as great as that obtained from other sources. The absence of non-specific reactions with these fluids weighed heavily in their favour. The effect of heat on antibodies and the relation between neutralizing and complementfixing antibodies in herpes simplex infections were discussed briefly. Certain precautions in the preparation of allantoic-amniotic antigens were noted.

Thanks are due to Dr. E. W. Hurst and to Dr. K. McCarthy for strains of virus.

\section{REFERENCES}

Bedson, S. P., and Bland, J. O. W. (1929). Brit. J. exp. Path., 10, 393.

Brown, J. A. H. (1953), Ibid, 34, 290.

Casals, J. (1949). Proc. Soc. exp. Biol., N.Y., 70, 339.

Casa Palacios. R. (1941). J. exp. Med., 74, 409.

Dudgeon, J. A. (1950). Journal of Clinical Pathology, 3, 239.

Felix, A., and Olitzki, L. (1929). Brit. J. exp. Path., 10, 26.

Gajdusek, D. C., Robbins, M. L., and Robbins, F.'C. (1952). J. Amer. med. Ass., 149, 235

Garabedian, G. A. (1953). The Immunological Basis of Recurrent Herpetic Infections. Ph.D. Thesis, Univ. of Minnesuta.

Herpetic Infections. Ph. D. Thesis, Univ. of Min
Hayward. M. E. (1949). Brit. J. exp. Path., 30. 520.

Henle, G., Harris, S., and Henle, W. (1948). J. exp. Med., 88, 133. Holzel, A., Feldman, G. V., Tobin, J. O'H., and Harper, J. (1953). Acta paediat., Uppsala, 42, 206.

Hoyle, L. (1948)., Monthly Bull. Minist. Hlth, Lond., 7, 114. 